\title{
ROLA STYLU NAUKOWEGO I URZĘDOWO-KANCELARYJNEGO NA KURSIE PRZYGOTOWUJĄCYM KANDYDATÓW DO PODJĘCIA STUDIÓW W POLSCE
}

\begin{abstract}
Słowa kluczowe: glottodydaktyka języka polskiego, styl naukowy, styl urzędowo-kancelaryjny
\end{abstract}

Streszczenie. Na podjęcie studiów w Polsce decydują się często obcokrajowcy, którzy nie znają języka polskiego zupełnie lub poznali go w niewielkim stopniu. Zmuszeni są więc w ciągu dwóch semestrów opanować nowy język na tyle, by w następnym roku akademickim podjąć studia na wybranym przez siebie uniwersytecie w Polsce. Podczas opracowywania programu kursu dla wymienionej grupy odbiorców i jego realizowania nie można ograniczać się do wykorzystania popularnych podręczników do nauczania języka polskiego jako obcego. Niezwykle istotnym elementem w przygotowaniu obcokrajowców do studiowania i uczestniczenia w życiu społeczności akademickiej jest opanowanie stylów naukowego i urzędowo-kancelaryjnego. Wyznaczniki owych stylów powinny być ćwiczone w sposób zintegrowany w ramach wszystkich sprawności językowych. W tym celu przyszli studenci winni analizować i opanowywać określone gatunki, wyrażać towarzyszące im funkcje językowe, umieć rozpoznawać, rozumieć i stosować wybrane struktury gramatyczne zarówno w rozumieniu ze słuchu i tekstów pisanych, jak i wypowiedzi ustnej oraz pisemnej.

\section{WPROWADZENIE}

Celem dwusemestralnego kursu, prowadzonego w Szkole Języka i Kultury Polskiej Uniwersytetu Śląskiego (SJiKP UŚ), jest przygotowanie jego uczestników obcokrajowców do podjęcia studiów w Polsce na wybranym przez siebie, wykładanym w języku polskim, kierunku. Słuchacze po intensywnej nauce języka planują podjąć studia zarówno na wydziałach humanistycznych (np. archeologia, międzynarodowe studia polskie, dziennikarstwo, politologia, stosunki

"mczempka@poczta.onet.pl, Uniwersytet Śląski w Katowicach, Szkoła Języka i Kultury Polskiej, pl. Sejmu Śląskiego 1, 40-032 Katowice. 
międzynarodowe, historia, pedagogika, prawo), jak i niehumanistycznych (np. zarządzanie, marketing, wychowanie fizyczne). Uczestnicy kursu przygotowawczego, kończąc go, powinni posługiwać się na tyle sprawnie językiem polskim i jego odmianami stylistycznymi, by móc z sukcesem studiować, uczestniczyć w życiu społeczności uniwersyteckiej, umieć zalegalizować swój pobyt w Polsce, a także zapewniać sobie odpowiednie warunki socjalne i bytowe. Obcokrajowcy powinni także wiedzieć, w jaki sposób dalej kształcić się językowo i umiejętnie korzystać ze wszelkich dostępnych źródeł (wykładów i seminariów, zadanych lektur, otaczającej ich kultury, Internetu, prasy, telewizji, radia), a także jakie działania podjąć w celu odnalezienia się na rynku pracy w trakcie studiów i po ich ukończeniu (przygotowanie i złożenie niezbędnych dokumentów, udział w rozmowie kwalifikacyjnej).

Kandydaci na studia w Polsce uczą się zwykle w SJiKP UŚ w kilku grupach o zróżnicowanym poziomie znajomości języka polskiego jako obcego. Kolejny rok przypada mi w udziale przygotowywanie programu i nauczanie $\mathrm{w}$ grupie o najniższym poziomie znajomości języka polskiego jako obcego, w której studenci przystępują do nauki, nie znając języka polskiego w ogóle lub znając go w niewielkim stopniu. W ostatnich trzech latach to właśnie obcokrajowcy rozpoczynający naukę języka polskiego jako obcego dla początkujących stanowią najliczniejszą grupę, zwykle mieszaną narodowościowo, której członkowie pochodzą nie tylko z krajów słowiańskich. Różni ich „przeszłość edukacyjna” i bagaż kulturowy, które zdobywali w zupełnie odmiennych systemach (Achtelik, Niesporek-Szamburska 2012, s. 199-218). Liczną grupę stanowią studenci z Białorusi, nieco mniejszą z Ukrainy i Mongolii, pojedyncze osoby pochodzą z Azerbejdżanu, Brazylii, Chin, Iraku, Kazachstanu, Korei Południowej, Rosji, Słowenii, Turcji, Uzbekistanu. Studenci, zaczynając naukę języka polskiego, nie są zwykle świadomi różnic pomiędzy ich rodzimym językiem a językiem docelowym, a także jak długa i intensywna czeka ich praca. Na początku kursu także ich plany często nie są do końca sprecyzowane - zdarza się, że w jego trakcie zmieniają decyzję co do wyboru kierunku studiów czy uniwersytetu, na którym podejmą naukę.

Program kursu zawiera 780 godzin lekcyjnych, z czego 600 godzin stanowi lektorat języka polskiego (4 jednostki lekcyjne dziennie), a także popołudniowe wykłady i zajęcia dodatkowe z zakresu terminologii specjalistycznej, literatury, kultury polskiej, wiedzy o języku polskim, historii Polski, socjologii. Program kursu językowego oparty jest na standardach wymagań dla poszczególnych poziomów zaawansowania językowego, określonych w Rozporządzeniu Ministra Edukacji Narodowej i Sportu z dnia 26 lutego 2016 r. w sprawie egzaminów z języka polskiego jako obcego (Dz.U. nr 191, poz. 1871) (2003). Podręcznikiem wiodącym wykorzystywanym w grupie początkującej jest ogólny podręcznik do 
nauki języka polskiego jako obcego ${ }^{1}$. Program lektoratu zawiera jednak szereg treści dodatkowych, uznanych przez prowadzących za konieczne do opanowania przed podjęciem studiów w Polsce zarówno w ramach kształconych sprawności językowych, jak i wiedzy socjokulturowej. W tekście chciałabym skupić się na lektoracie języka polskiego, który od trzech lat współprowadzę w grupach o najniższym poziomie znajomości języka polskiego jako obcego.

Program kursu, opracowany na początku, stale był uaktualniany ze względu na dynamiczną sytuację panującą w grupie. Podlegała ona różnorakim zmianom, także osobowym, co wymagało stałego modyfikowania treści w nim zawartych. Przed studentami pojawiały się ciągle nowe wyzwania. Stawiając im czoła, ujawniali odmienne postawy wynikające $\mathrm{z}$ różnic kulturowych i edukacyjnych np. stopień gotowości do podejmowania komunikacji (studenci z Mongolii czy Chin prezentowali postawę zdecydowanie wycofaną wobec studentów z Białorusi czy Ukrainy). W kursie brały także udział osoby, u których można było podejrzewać dysortografię (choć nie była ona nigdy zdiagnozowana), a także rozszczepienie wargi i podniebienia (student miał wyraźną bliznę, sam nie inicjował komunikacji, mówił cicho i niepewnie). Wstępne założenia były więc stale aktualizowane. Pierwszy semestr zawierał więcej treści dotyczących mówienia, rozumienia ze słuchu i rozumienia tekstów pisanych. Drugi, ze względu na rosnące kompetencje studentów, koncentrował się na sterowanym i niesterowanym pisaniu tekstów (opisów, podań, CV, streszczeń, skarg, recenzji, krótkich rozprawek, sprawozdań, tekstów argumentacyjnych), budowaniu krótszych i dłuższych wypowiedzi ustnych np. wygłaszaniu prezentacji, wyrażaniu aprobaty bądź sprzeciwu, prowadzeniu rozmowy kwalifikacyjnej.

Każdy tydzień nauki tworzył spójną całość - zajęcia były podporządkowane jednemu tematowi, w ramach którego ćwiczono poszczególne sprawności. Zajęcia piątkowe wieńczyło powtórzenie poznanych treści, a pierwszego dnia tygodnia studenci zawsze pisali 30-40 minutowy test, sprawdzający stopień opanowania zrealizowanego materiału.

\section{POLSKI JEZZYK AKADEMICKI A STYL NAUKOWO-KANCELARYJNY}

O specyfice kursu przygotowującego do podjęcia studiów decyduje usytuowanie go w ramach uniwersytetu, jego akademickość i nadrzędny cel, jakim jest gotowość do odbycia studiów pierwszego stopnia oraz sprawne komunikowanie

${ }^{1}$ Były to między innymi: Polski. Krok po kroku 1 autorek: Iwona Stempek, Anna Stelmach, Sylwia Dawidek, Aneta Szymkiewicz, Kraków 2013; Hurra!!! Po polsku 1 autorek: Aneta Szymkiewicz, Małgorzata Małolepsza, Kraków 2010; Dzień Dobry 1 i 2 autorek: Aleksandra Janowska, Magdalena Pastuchowa, Koszęcin 2008. 
się z pracownikami uniwersytetu i instytucji typu: biblioteki, urzędy, akademiki, potencjalne miejsca pracy. Podjęcie studiów w Polsce, uczestnictwo w życiu studenckim, konieczność załatwiania formalności związanych z mieszkaniem w akademiku lub wynajętym/kupionym mieszkaniu, a także pobytem w Polsce wymaga od studentów przede wszystkim opanowania oficjalnych odmian polszczyzny - stylu naukowego oraz stylu urzędowo-kancelaryjnego.

Styl naukowy, jako „funkcjonalna odmiana języka literackiego (...) o szczególnym ukształtowaniu słownictwa i składni (...) z wypowiedziami mającymi charakter logicznie zretoryzowanych wywodów" (Stownik terminów literackich - STL 2008, s. 535), niezbędny jest studentom do pozyskiwania wiedzy podczas wykładów i seminariów, rozumienia tekstów naukowych, także do wykorzystywania zdobytych informacji i samodzielnego wygłaszania referatów, przedstawiania prezentacji multimedialnych oraz przygotowywania i pisania prac zaliczeniowych. Studenci muszą zatem posługiwać się stylem naukowym w jego odmianie ustnej i pisemnej (Gajda 1999, s. 24) oraz rozumieć teksty o wzorcach scjentystycznych nacechowanych dowodowością, jak i bardziej retorycznych wykorzystujących „linię persfazyjno-tropiczną"2. Przygotowanie do pierwszych prób pisania tekstów stylem naukowym sprowadza się do wyjaśniania zasad komunikacyjnego współdziałania („,por. maksymy H.P. Grice’a (1977): ilość, jakość, stosunek, sposób i grzeczność oraz J. Habermasa (1981): zrozumiałość, prawda, wiarygodność i stosowność", za: Gajda 1999, s. 29) przy zachowaniu poprawności językowej. Rozumienie i posługiwanie się stylem naukowym wymaga także od studentów świadomości, umiejętności rozpoznania i posługiwania się: terminami specjalistycznymi, leksyką ogólnonaukową (w dużej mierze abstrakcyjną i obcego pochodzenia) i książkową, środkami spajającymi tekst i ,wyrażającymi postawę nadawcy wobec przekazywanych treści”, znajomości określonych struktur gramatycznych (Gajda 2001, s. 188-189). Jak podaje Stanisław Gajda „spośród form jego [stylu naukowego - M.C.-W.] kategorii szczególnie częste są np. tryb oznajmujący (90\%), aspekt niedokonany $(80 \%)$, czas teraźniejszy (85\%, głównie w znaczeniu niedokonanym) i 3. osoba liczby pojedynczej (60\%, bardzo często w znaczeniu bezosobowym). (...) Przeważają (...) zdania złożone podrzędnie (...). Składowe w obrębie zdań złożonych są znacznie dłuższe (...)", rzeczowniki i przymiotniki dominują nad czasownikami (Gajda 2001, s. 188-189). Istotna jest też rozczłonkowana struktura z wyraźnym wstępem, środkiem i zakończeniem oraz tekstami pomocniczymi, jak: przypisy, bibliografia, aneks, indeks (Gajda 2001, s. 189). W ramach omawianego stylu studenci zapoznają się z przykładami (na niskim poziomie znajomości języka - fragmentami) gatunków oficjalnej komunikacji naukowej (artykuł, monografia, studium, rozprawa i referat, biblio-

${ }^{2}$ „Nowy styl sięga po tropy i obrazowanie oraz beletrystyczną manierę wykładu, nie stroni od gawędowości i kolokwializmów, esejowości, felietonowości, gry znaczeniem i budową słowa" (Gajda 1999, s. 28). 
grafia, hasło encyklopedyczne, recenzja naukowa, podręcznik, zbiór ćwiczeń, wykład, pogadanka) oraz nieoficjalnej (rozmowa, konsultacja, dyskusja, list) (Gajda 2001, s. 189-190). Ostatni z wymienionych gatunków przybiera obecnie raczej postać e-maila.

Z kolei silne zinstytucjonalizowanie kontaktów uniwersyteckich w jego działalności administracyjno-prawnej (Wojtak 2001, s. 155) narzuca „duży stopień konwencjonalizacji i schematyczności języka” cechujący styl urzędowo-kancelaryjny (STL 2008, s. 537). Jak zauważa Maria Wojtak, „do podstawowych cech stylu urzędowego można zaliczyć (...): dyrektywność, bezosobowy charakter wypowiedzi (bezosobowość), precyzyjność, standardowość" (Wojtak 2001, s. 155). Dyrektywność realizowana jest w postaci nakazów, zakazów, pozwoleń, co z kolei związane jest z użyciem trybu rozkazującego oraz czasowników modalnych ${ }^{3}$; bezosobowość gramatycznie wyraża się w nieosobowych formach czasownika i stronie biernej; precyzja - w użyciu słownictwa specjalistycznego kosztem ekspresywnego i kolokwialnego; standardowość - w szablonowości konstrukcji, powtarzalności jej składników i przejrzystości (Wojtak 2001, s. 160-167). Stałym zabiegiem jest także stosowanie ,aktów oficjalnej grzeczności” (np. zwracam się z uprzejma prośba, uprzejmie proszę, dziękuję za rozpatrzenie mojej prośby) oraz utrzymywanie przewagi rzeczowników nad innymi częściami mowy (Malinowska 2013, s. 470-474). Struktura tekstów urzędowych ,składa się z trzech segmentów, przy czym pierwszy jest nawiązaniem kontaktu, drugi jest aktem informacyjnym - wyjaśnia sprawę i uzasadnia decyzję, trzeci jest aktem etykietalnym - zawiera pozdrowienia lub zwrot grzecznościowy z poważaniem oraz podpis" (Malinowska 2001, s. 476). Cechuje je też rozbudowana rama tekstowa zawierająca szereg informacji faktograficznych (data, miejsce, imię i nazwisko nadawcy oraz/lub nazwa odbiorcy, dane kontaktowe, pieczęcie, podpisy) (Malinowska 2001, s. 475-476). Gatunki realizujące styl urzędowo-kancelaryjny istotne dla rozważań zawartych w niniejszym tekście to formy „obsługujące komunikację obywatela z instytucją: podania, skargi, życiorysy (obecnie najczęściej curriculum vitae)" oraz listy motywacyjne, wnioski, umowy, reklamacje, odwołania, upoważnienia (Wojtak 2001, s. 158, Malinowska 2013, s. 474-479).

Oba style uczestnicy kursu muszą opanować na tyle, by sprawnie komunikować się z pracownikami naukowymi oraz administracyjnymi uniwersytetu i przedstawiać swe potrzeby w mowie i piśmie. Na szczególną uwagę zasługują rozbudowane zwroty adresatywne stosowane w tytulaturze uniwersyteckiej, których prawidłowe użycie często warunkuje podjęcie komunikacji i fortunność realizowanego aktu mowy. Błędy w tym zakresie i odstępstwa od przyjętej normy zdarzają się zarówno w mowie, jak i piśmie.

Dodajmy, iż niejednokrotnie uczestnicy kursu przygotowawczego spotykają się $\mathrm{z}$ wymienionymi odmianami języka literackiego jedynie w języku polskim.

${ }^{3}$ M. Wojtak wymienia: móc, musieć, powinien, wolno, należy (Wojtak 2001, s. 157). 
Bardzo rzadko na kursie zdarzały się osoby, które odbyły już część studiów w swoim kraju, pisały prace, a nawet artykuły naukowe, ubiegały się o pracę na jakimś stanowisku i ją otrzymały, a zatem miały kontakt z językiem sformalizowanym i schematycznym. Często dopiero na lekcjach języka polskiego jako obcego młodzi ludzie mają do czynienia z językiem „logicznie silnie zrygoryzowanym” (STL 2008: 535), specyficzną terminologią i utartymi skonwencjonalizowanymi zwrotami, określonymi formami gramatycznymi służącymi wymienionym stylom, właściwymi tym stylom gatunkami (STL 2008: 537) i obowiązującą na uniwersytetach polskich etykietą oraz zwyczajami, nieraz diametralnie różnymi od tych panujących na uniwersytetach rodzimych.

Duże znaczenie ma także interferencja językowa, w tym przypadku zdecydowanie negatywnie oddziałująca na opanowanie języka drugiego, a także określona postawa i motywacja wobec nauki języka. Osoby pochodzące z krajów niesłowiańskich są często silniej zmotywowane do nauki i pracy, natomiast podobieństwo językowe i sukces w komunikacji nieformalnej wpływa na studentów ze słowiańskich grup językowych nieraz demotywująco. Utwierdzają się bowiem w przekonaniu, że język, jakim posługują się na ulicy czy w akademiku, będzie im służył w tym samym stopniu na uczelni wyższej. Często przedstawiciele tej ostatniej grupy nie uznają i nie dostrzegają pewnych niewielkich różnic pomiędzy językami, a tym samym ich nie postrzegają ich jako znaczących. $Z$ tego powodu nie przykładają do ich opanowania zbyt wielkiej uwagi. Mam tu na myśli chociażby pomijanie form adresatywnych przy zwracaniu się do osób starszych lub o wyższym statusie.

Biorąc pod uwagę powyższe obserwacje, sądzę, że zapoznanie studentów z elementami stylu naukowego i urzędowo-kancelaryjnego i ich opanowanie powinno być istotnym elementem procesu przygotowania uczestników kursu do podjęcia studiów w Polsce, z czym wiąże się wybór określonych tematów, funkcji językowych, struktur gramatycznych. Poniżej chciałabym przedstawić pewne propozycje wykorzystywane w ramach kursu przygotowawczego, mające za zadanie przybliżać i kształcić oba powyższe style. Opis wprowadzania poszczególnych elementów chciałabym przedstawić w ramach poszczególnych sprawności językowych, które kształcone były w sposób zintegrowany (Komorowska 2009 , s. 210-223), na potrzeby niniejszego wywodu zostały jednak rozdzielone. Sprawności omawiam, rozpoczynając od mówienia, poprzez rozumienie ze słuchu i sporządzanie notatek, rozumienie tekstów pisanych, kończąc na pisaniu tekstów. Nie omawiam odrębnie poprawności gramatycznej, gdyż określone formy pojawiają się w danych gatunkach (np. formy bezosobowe w tekście naukowym). Podane przykłady ćwiczeń w ramach poszczególnych sprawności nie stanowią zamkniętej listy i są jedynie propozycją, która może być stale rozwijana i uzupełniana. 


\section{PROPOZYCJE DYDAKTYCZNE}

\subsection{MÓWIENIE}

Część najnowszych podręczników kursowych i materiałów pomocniczych, opierając się na wąsko rozumianym podejściu komunikacyjnym, zawęża komunikację do mowy (Dębski 1996, s. 48), a tę z kolei do sytuacji życia codziennego, w której naczelne miejsce zajmuje dialog, co często wiąże się z wykorzystaniem tej właśnie formy w procesie glottodydaktycznym. Dialog jako naturalna forma pozyskiwania i wymiany informacji doskonale sprawdza się na każdym poziomie nauczania języka, a szczególnie na najniższym, lub podczas krótkiego kursu zorientowanego na szybką naukę języka w określonych sytuacjach komunikacyjnych. Jednakże zbyt silne skupienie się na dialogach w przypadku grup wyższych niż poziom A0 prowadzi do pewnych ograniczeń w komunikacji i zahamowania rozwoju wszystkich sprawności. Zdarza się bowiem, że dialogizującymi partnerami są często osoby młode, pełniące mało zróżnicowane role społeczne i będące w podobnym wieku (koleżanki na zakupach, studentki bądź studenci, uczestnicy kursu językowego, przyjaciele rozmawiający o mieszkaniu, jedzeniu, ubraniach, umawiający się na spotkanie, opowiadający o przeszłości), a interakcja realizowana jest często z pominięciem form oficjalnych (zakupy w sklepie/na targu, rozmowa telefoniczna ${ }^{4}$ ). Forma dialogu pomiędzy równymi sobie uczestnikami interakcji narzuca $\mathrm{w}$ dużym stopniu nieformalność prowadzonego dyskursu, a zwroty oficjalne są pomijane. Podejście takie nie przesądza, oczywiście, o nieprzydatności danego podręcznika, zwraca jednak uwagę, że język oficjalny na kursie przygotowującym do podjęcia studiów powinien być uzupełniony i ćwiczony.

Brak oficjalności sprzyja nauce i kreowaniu przyjaznej, zmniejszającej dystans atmosfery. Kształtuje jednak wśród obcokrajowców przeświadczenie, że w nieformalny sposób mogą także porozumiewać się z wykładowcami, np. używając form: Pani Aniu!, Pani Kasiu! lub, częściej, z pominięciem formy wołacza: Pani Ania!, czy stosując konstrukcje adresatywne w drugiej osobie liczby mnogiej (dotyczy to szczególnie osób zza wschodniej granicy). Później skutkuje to nieporadnością w używaniu poprawnych form oficjalnych wobec osób starszych i o wyższym statusie lub unikaniem interakcji (co wyraża się np. wysyłaniem do wykładowcy pustych e-maili zaopatrzonych jedynie w załącznik z zadaną pracą). Zdecydowanie odmienne bowiem zwyczaje i inna etykieta w zakresie tytulatury

${ }^{4}$ Przytaczam fragment rozmowy telefonicznej zawarty w jednym z popularniejszych podręczników do nauki języka polskiego jako obcego: „Dziewczyna: Halo?/ Angela: Eeee, czy to numer 606999741?/ Dziewczyna: Eeee, nie wiem (...); (Polski, Krok po kroku 1, 2013, s. 147). 
mogą panować i panują na zagranicznych uniwersytetach, chociażby w Brazylii czy Gruzji. Studenci, którzy nie przećwiczyli i nie utrwalili określonych zachowań w sytuacji oficjalnej, nie będą mogli się w niej swobodnie odnaleźć.

W ćwiczeniu oficjalnych form komunikacyjnych niezwykle pomocna okazuje się metoda symulacyjna - ,zastąpienie sytuacji rzeczywistej przez jej model w celach zabawowych (gra symulacyjna) bądź dydaktycznych" (Okoń 1992, s. 198). Symulacja wykorzystuje w klasie dramę - uczestnicy odgrywają narzucone im role charakterystyczne dla danej sytuacji. W przypadku prowadzonych grup nieraz w grach brali udział także Polacy - studenci odbywający praktykę. Uczestnikom kursu narzucane były zwykle role studentów, stawiające ich w obliczu różnych problemów (uzyskiwanie informacji na temat dyżurów pracowników, prośba o wydanie, podstemplowanie i wyrobienie nowej legitymacji, skorygowanie błędów w indeksie lub jego ponowne wydanie, przełożenie egzaminu, usprawiedliwienie nieobecności, umożliwienie powtórnego zdawania egzaminu). Studenci, realizując narzucone im role, rozmawiali także z pracownikami sekretariatów, dziekanatów i administracji, którzy wcześniej wyrazili zgodę na udział w ćwiczeniach. Każdorazowo studenci wcześniej zostali zapoznani z formą dialogową, którą mieli realizować, oraz odpowiednią leksyką, funkcjami językowymi, jak i niezbędnymi formami gramatycznymi (przykłady narzuconych ról podaję w Aneksie, ćw. 1).

\subsection{ROZUMIENIE ZE SŁUCHU I SPORZĄDZANIE NOTATEK}

Poza ćwiczeniami ze słuchu, uwzględnionymi zarówno w podręczniku, jak i zeszycie ćwiczeń, studenci uczestniczyli we wspomnianych wcześniej wykładach i ćwiczeniach, prowadzonych w języku polskim, ale przygotowanych z myślą o obcokrajowcach, jak: historia Polski, socjologia języka, międzynarodowe relacje kulturowe, ćwiczenia z kompozycji tekstu pisanego i mówionego oraz tekstów i kontekstów. Język wykładowy był nieco łatwiejszy niż podczas standardowych zajęć dla studentów Polaków. Konwersatoria lub wyklady kończyły się egzaminem w formie ustalonej przez prowadzącego. Studenci sporządzali więc z zasłyszanych podczas wykładów treści notatki; byli do tego przygotowywani podczas zajęć lektoratowych. Z nagrań, krótkich wypowiedzi prowadzącego, innych kolegów referujących wybrane zagadnienia, spotkań i wykładów gościnnych, w których mieli okazję wziąć udział, wynotowywali podstawowe informacje (słowa klucze, terminy, dane faktograficzne), a następnie w parach wymieniali się zasłyszanymi informacjami, by następnie zadawać pytania dotyczące poznanych treści innym studentom. Opracowywane w ten sposób notatki, były coraz dokładniejsze. 
Dodatkowo, w drugim półroczu studenci poddawani byli treningowi rozumienia wiadomości telewizyjnych, dzięki czemu uzyskiwali wiedzę realioznawczą, dotyczącą zarówno Polski, jak i Europy Środkowej; tematami wiadomości były najczęściej: bieżące wydarzenia polityczne i gospodarcze, prezentacje sylwetek znanych osób, relacje z festiwali, spotkań, akcje charytatywne, klęski żywiołowe, rocznice wydarzeń historycznych. Oglądanie fragmentu wiadomości poprzedzało zapoznawanie się z leksyką i zwrotami mającymi się pojawić w zasłyszanym tekście, czemu towarzyszyły również ćwiczenia fonetyczne. Następnie studenci oglądali całość przekazu, potem w parach omawiali uzyskane informacje, a na koniec podsumowywali je na forum grupy. Dodatkowo utrwalali zasłyszane zwroty na podstawie materiału ikonograficznego. Efektem finalnym było napisanie krótkiej notatki prasowej odnoszącej się do tematyki poruszanej w informacjach. Poziom rozumienia tekstów słuchanych sukcesywnie wzrastał, czego dowodem było coraz sprawniejsze relacjonowanie wiadomości.

Tego typu ćwiczenia dawały możliwość zapoznania słuchaczy zarówno z treściami dotyczącymi Polski - kulturą, historią, informacjami gospodarczymi, politycznymi - jak i jej sąsiadów i świata. Były także okazją do słuchania naturalnych wypowiedzi, w których pojawiał się czynnik dystorsyjny - wypowiedzi były urywane, pełne emocji, realistyczne. Zadanie studentów często polegało na zmianie wypowiedzi potocznej na oficjalną. Wykorzystanie aktualnych materiałów audiowizualnych pomagało utrzymać zainteresowanie słuchaczy tematami dotyczącymi bezpośrednio ich życia i ojczyzny, nie zawsze zresztą łatwymi i wywołującymi nieraz sprzeczne emocje, np. rocznica katastrofy w Czarnobylu, problemy czy afery finansowe dotyczące określonych krajów lub przebiegające $\mathrm{z}$ udziałem danych polityków, klęski żywiołowe (zob. Aneks, ćw. 2).

\subsection{ROZUMIENIE TEKSTÓW PISANYCH}

Niezwykle ważną sprawnością, która może być kształcona samodzielnie w toku własnej pracy ucznia jest czytanie (Komorowska 2009, s. 188). Zarówno czytanie intensywne (teksty książkowe), jak i ekstensywne (czytanie dla przyjemności, które służy relaksowi bez ingerencji nauczyciela) (Dakowska 2005: s. 206-207) przyczynia się do znacznych postępów w opanowaniu języka polskiego. Jak pisze Hanna Komorowska ,sprawność ta odgrywa szczególną rolę w nauce języka. (...) Czytanie jest więc najskuteczniejszym wsparciem opanowania pozostałych sprawności, gdyż w toku czytania następuje stałe powtarzanie i utrwalanie poznanych wyrazów, zwrotów i struktur" (2009, s. 188). Inspirujące wydały mi się założenia metody Symultaniczno-Sekwencyjnej Nauki Czytania, opracowanej przez Jadwigę Cieszyńską z myślą o dzieciach, u których zdiagnozowano jakiś deficyt mowy 
połączony często z inną jednostką chorobową, jak i tych bez określonej diagnozy. Metoda ta polega na stopniowym powtarzaniu logotomów, prostych słów i zdań, co prowadzi do ich rozpoznawania i rozumienia, a wreszcie nazywania i samodzielnego globalnego czytania (Cieszyńska 2006, s. 13). Czytanie odciąża zatem mówienie, jest czymś osiągalnym, w czym można odnieść sukces. Stopień trudności lektury jest rozłożony w czasie i dostosowany do możliwości czytającego.

Również w przypadku obcokrajowców czytanie może znacznie pomagać w nauce języka polskiego. Teksty przygotowane dla cudzoziemców powinny spełniać kilka warunków, tak by nie zniechęcić ich w początkowym okresie nauki do czytania, a wręcz przeciwnie, zachęcić ich do sięgania po słowo pisane, dać im poczucie satysfakcji z przeczytanego i zrozumianego tekstu, by ostatecznie zwiększyć ich motywację do nauki języka polskiego. Jak pisze Anna Seretny, tekst taki powinien zawierać ograniczoną leksykę dostosowaną do poziomu znajomości języka, niski stopień pojawiania się wyrazów nieznanych $(2-5 \%$, co oznacza zaledwie 5 wyrazów nieznanych na 100) oraz wysoki stopień redundancji (Seretny 2014, s. 11-25). Tekst powinien być ponadto spójny, ciekawy, tak by sprawiać czytającemu przyjemność. Teksty uproszczone metodą adaptacji i symplifikacji wewnątrztekstowej (Seretny 2014, s. 14-17) mogą za pierwowzór brać zarówno tekst literacki, prasowy, jak i popularnonaukowy i naukowy.

Kierując się powyższymi założeniami, opracowałam dla studentów szereg tekstów dotyczących różnych tematów (gospodarka, kultura, historia, polityka). Były to uproszczone teksty, których bazę stanowiły artykuły naukowe i popularnonaukowe. Średnia długość takiego tekstu wynosiła 300-400 słów, a stopień pojawienia się wyrazów nieznanych wynosił ok. 5\%. Studenci każdorazowo przygotowywali się do lektury poprzez ćwiczenia wprowadzające, następnie czytali tekst, wykonywali do niego ćwiczenia, uzupełniali luki, kończyli zdania pojawiające się w tekście. Słuchacze spotykali się kilkukrotnie z danym tekstem, który stawał się podczas kolejnych zajęć pretekstem do dyskusji lub pisania streszczenia, tekstu argumentacyjnego lub dyskusji czy polemiki. Kształcenie sprawności czytania miało więc za zadanie umożliwić studentom wielokrotny kontakt z danym słownictwem i służyło utrwalaniu trudnej leksyki, jak i całych struktur pojawiających się w stylu naukowym (przykład tekstu uproszczonego podaję w Aneksie, zob. ćw. 3).

\subsection{PISANIE}

Polscy studenci w przeciągu pięciu lat muszą napisać co najmniej dwie prace: licencjacką i magisterską oraz szereg innych zadanych na zaliczenie przedmiotów, co wymaga przyswojenia sobie zarówno reguł poprawnej pisowni, jak 
i rozumienia oraz sprawnego posługiwania stylem naukowym w ramach określonych form. Muszą także opanować szereg gatunków należących do stylu urzędowo-kancelaryjnego. Przedstawienie prośby, wniosku, skargi wymaga zawsze złożenia odpowiedniego pisma. Kontakty z nauczycielami akademickimi wymuszają często przesłanie wiadomości $\mathrm{w}$ formie e-mailowej; wiążą się $\mathrm{z}$ tym działania takie, jak: załączanie prac, pytanie o termin dyżuru, usprawiedliwienie nieobecności itp. Kształcenie sprawności pisania staje się zatem wyjątkowo ważne, ponieważ bez określonego wzorca, ćwiczeń i zaleceń nauczyciela niezwykle trudno studentowi samodzielnie rozwinąć omawianą sprawność. Sądzę, że niepotrzebnie wokół pisania narosło wiele opinii głoszących, iż mogą to efektywnie robić tylko osoby posiadające talent pisarski, z czego wynika, iż osoby go pozbawione nie powinny zajmować się pisaniem (Łuczyński, Maćkiewicz 2000, s. 46), a tymczasem rzeczywistość uniwersytecka wymaga od studentów biegłości w zakresie tworzenia różnorakich form pisemnych, w tym - mających charakter oficjalnych pism. Nieprawidłowy układ typograficzny pisma lub pracy, czy też błędy ortograficzne, mogą zadecydować o nieprzyjęciu dokumentu lub wystawieniu oceny negatywnej na studiach.

Obserwowane jest także stałe zmniejszanie się znaczenia sprawności pisania, w sytuacji gdy ma ono charakter wspomagający, jak notowanie, przepisywanie (Komorowska 2009, s. 146-151). Jako rodzimi użytkownicy języka polskiego mamy coraz mniejszy kontakt z odręcznym pismem na rzecz zapisu komputerowego (gdzie pomocne są funkcje autokorekty), stale wzrasta także liczba zdiagnozowanych przypadków dysleksji i dysortografii, co także dotyczy obcokrajowców, którzy rzadko posługują się pismem odręcznym w swoich własnych językach. Nie są w stanie wówczas poprawnie przepisywać liter, a co ważniejsze, zanotować wypowiedzi zasłyszanej podczas zajęć lektoratowych i wykładów. Cudzoziemcy pisząc, często kopiują litery drukowane, pomijają znaki diakrytyczne lub stosują znaki przeniesione $\mathrm{z}$ własnego języka lub też znaki przez siebie zmodyfikowane (np. serduszka i kółeczka nad „i”), co uznawane jest za błąd (Lipińska 2010, s. 15). Studenci zagraniczni powinni zatem rozpocząć kurs od nauki prawidłowego zapisu polskiego alfabetu.

Koncentrując się na komunikacji, można dojść do wniosku, że „sprawność pisania jest umiejętnością stosunkowo najmniej, a przynajmniej najrzadziej, potrzebną przeciętnemu użytkownikowi języka. W codziennym toku posługiwania się językiem obcym pisanie zazwyczaj ogranicza się do wypełniania podstawowych formularzy, pisania okolicznościowych kartek i listów" (Komorowska 2009, s. 205), zajmuje ono ostatnie miejsce w komunikacji międzyludzkiej po słuchaniu, mówieniu i czytaniu (Steil, Miller 1982, s. 16). Zauważalna jest coraz większa marginalizacja pisania (Dębski 1996, s. 48).

Ograniczanie pisania do niezbędnego minimum jest zrozumiałe na kursie ogólnym języka obcego, inaczej jednak sytuacja wygląda podczas studiów (szcze- 
gólnie humanistycznych). Sprawne tworzenie i redagowanie tekstów staje się więc warunkiem koniecznym do funkcjonowania w społeczności akademickiej, co więcej - wymaga udziału innych sprawności, gdyż pozwala wkroczyć „,W sferę rozwijania umiejętności ogólnointelektualnych" (Dębski 1996, s. 48). W wielu przypadkach staje się także nieodzownym warunkiem odbywania praktyk uniwersyteckich, wyjazdów (chociażby w ramach programu Erasmus + ) i brania udziału w konferencjach, a ostatecznie podjęcia w przyszłości pracy i jej wykonywania (z czym wiąże się umiejętność pisania CV, podania, listu motywacyjnego).

Program kursu przygotowawczego koncentrował się na następujących formach pisemnych, których podstawy tworzenia studenci powinni opanowaćs: opis (sposobu spędzania wolnego czasu, osoby, rodziny, tradycji i kuchni danego kraju, miejsca, np. pokoju, mieszkania, domu, miasta, fotografii); list/e-mail do kolegi z Polski; formy skonwencjonalizowane jak: życzenia, gratulacje, pozdrowienia skierowane do koleżanki/kolegi z Polski (nieoficjalne) i do wykładowcy (oficjalne); umawianie się na spotkanie (e-mail, SMS) (nieoficjalne) i zaproszenie na spotkanie (e-mail, forma tradycyjna) (oficjalne); rezerwacja np. pokoju hotelowego (e-mail); podanie (np. o przyznanie pokoju jednoosobowego, stażu naukowego, zmianę kierunku, przedłużenie sesji); prośba (np. o zwolnienie z zajęć); ogłoszenie (poszukiwanie mieszkania, współlokatora, pracy); charakterystyka osoby; list motywacyjny, Curriculum Vitae; opowiadanie; reklamacja; upoważnienie; notatka; tworzenie planu; streszczenie; relacja z przebiegu zdarzeń (wypadek, wycieczka, podróż); sprawozdanie; krótki opis wydarzeń historycznych; recenzja książki, filmu, sztuki teatralnej, koncertu; teksty argumentacyjne; referat na wybrany temat przygotowany także jako prezentacja multimedialna, będąca uzupełnieniem wygłaszanego referatu; zapis bibliograficzny. Dobór tekstów zdecydowanie przekraczał poziom znajomości języka polskiego jako obcego określony w podręczniku kursowym na A1/A2. Trzeba jednak uznać, że zapoznanie słuchaczy z wymienionymi formami jest konieczne, by sprawnie poruszali się w rzeczywistości akademickiej oraz poza nią.

Wielu z wymienionych form wypowiedzi uczestnicy kursu nigdy nie pisali i możliwe, że nie będą pisać, w języku ojczystym. Było to więc w dużej mierze pierwsze zetknięcie się z danym gatunkiem, który nie ma odniesienia do praktyki językowej studentów w ich własnym języku. Sytuacja ta wymagała więc od prowadzącego przygotowania ćwiczeń stylistycznych uwzględniających styl naukowy i urzędowo-kancelaryjny, zwrócenia uwagi na rozwijanie krytycznego myślenia, prowadzenia logicznych wywodów, gromadzenia argumentów zmierzających do konkluzji na jakiś temat, „dowodzenia i dokumentowania prezentowanych twierdzeń" (STL 2008, s. 535), a ponadto wykorzystywania określonej terminologii i używania wykładników gramatycznych obu stylów: wołacza w formach adresatywnych, form nieosobowych, czasowników modalnych i bezosobowych,

${ }^{5}$ Zestaw form pisemnych ustalałam razem z Anną Krzystolik. pracownikiem SJiKP UŚ. 
strony biernej, zdań złożonych podrzędnie (Gajda 2001, s. 183-199; Wojtak 2001, s. 155-171, Malinowska 2013, s. 467-486).

Problemy z przygotowaniem dłuższej samodzielnej, logicznie uzasadnionej wypowiedzi niejednokrotnie związane są z budowaniem krótkich i zdawkowych odpowiedzi w języku ojczystym użytkownika i przyzwyczajeniu jedynie do dialogizowania o sprawach życia codziennego. Jak zauważa Ewa Lipińska, w trakcie pisania (tworzenia) tekstu, niedopuszczalne jest thumaczenie tekstów ze swojego języka, trzeba natomiast „,zmusić się do myślenia w języku docelowym” (Lipińska 2010, s. 13). Analizując tekst, należy pokazać studentom inny sposób nabywania umiejętności tworzenia tekstu niż tłumaczenie z własnego języka czy języka angielskiego. Wieloetapowy proces kształcenia tej sprawności i nacisk na pisanie kontrolowane przynosi spodziewane efekty. Zwiększając stopień skomplikowania tekstu, zapoznajemy studentów z formami coraz trudniejszymi i dłuższymi, które opanowują poprzez poprawne kopiowanie, a dopiero później wykorzystujemy pisanie sterowane i na końcu wolne. $Z$ pomocą przychodzi tutaj specyfika gatunków urzędowych, które są w dużym stopniu skrystalizowane i kliszowe, przez co stosunkowo łatwo dają się kopiować i uzupełniać odpowiednimi treściami indywidualizującymi wzór (Wojtak 2001: 155-170) ${ }^{6}$ (przykładowe ćwiczenie podaję w Aneksie, zob. ćw. 4).

\section{SUKCESY I PORAŻKI - PODSUMOWANIE}

O ostatecznym wyniku kursu przygotowującego do podjęcia studiów decydują sami studenci - ich postawa, motywacja i gotowość do podjęcia trudu nauki. To w ich rękach spoczywa ich własny los i przyszłość. Osoby przekonane o swoich wysokich sprawnościach językowych, dobrze radzące sobie w codziennych sytuacjach komunikacyjnych, ale słabo zmotywowane do nauki, nie mogą liczyć na sukcesy w zakresie opanowania języka używanego w realiach uniwersyteckich. Nauka polszczyzny, pomimo iż nastręcza wielu problemów, może przynieść spodziewany efekt. Przekonują mnie o tym przypadki studentów niepochodzących z krajów słowiańskich, którzy w ciągu roku osiągnęli bardzo dobre wyniki w nauce: Iranki, która pod koniec kursu posługiwała się płynną polszczyzną w różnych rejestrach językowych, studenta z Angoli, który bardzo szybko przeszedł do wyższej grupy językowej, a także studentki z Mongolii, wykazującej się ogromną pracowitością i również doskonale radzącej sobie w sytuacjach wyma-

${ }^{6}$ Przykładem podręcznika przeprowadzającego studentów wieloetapowo przez proces pisania danego gatunku jest praca Andrzeja Ruszera pt. Oswoić tekst: podręcznik kompozycji i redakcji tekstów użytkowych dla poziomów B2 i C1, Kraków 2011. Jest to jednak propozycja skierowana do studentów zaawansowanych. 
gających użycia języka oficjalnego. Zajęcia nie były łatwe także dla nauczyciela, który musiał indywidualnie traktować każdego studenta, biorąc pod uwagę jego mocne i słabe strony. Wspomniani studenci przekuli swoje początkowe porażki w sukces, poświęcając nauce nieporównywalnie więcej czasu niż studenci z krajów słowiańskich.

\section{BIBLIOGRAFIA}

Achtelik A., Niesporek-Szamburska B., 2012, Dialog kultur, czyli o podręczniku dla dzieci do nauczania języka polskiego jako drugiego, w: „Postscriptum Polonistyczne”, Katowice, s. $199-218$.

Cieszyńska M., 2006, Kocham uczyć czytać, Kraków.

Dakowska M., 2005, Teaching English as a Foreign Language, Warszawa.

Dębski R., 1996, Komputer w nauczaniu języka polskiego. Przetwarzanie języka w programach dydaktycznych, Kraków.

Gajda S., 1999, Język nauk humanistycznych, w: W. Pisarek (red.), Polszczyzna 2000. Orędzie o stanie języka na przełomie tysiącleci, Kraków, s. 12-31.

Gajda S., Styl naukowy, 2001, w: J. Bartmiński (red.), Współczesny język polski, Lublin, s. $183-199$.

Komorowska H., 2009, Metodyka nauczania języków obcych, Warszawa.

Lipińska E., 2010, Nie ma róży bez kolców, Kraków.

Łuczyński E., Maćkiewicz J., 2000, Językoznawstwo ogólne. Wybrane zagadnienia, Gdańsk.

Malinowska E., 2013, Styl - dyskurs - komunikacja urzędowa, w: E. Malinowska, J. Nocoń, U. Żydek-Bednarczuk (red.), Style współczesnej polszczyzny. Przewodnik po stylistyce polskiej, Kraków, s. 474-479.

Okoń W., 1992, Stownik pedagogiczny, Warszawa.

Skudrzyk A., Warchala J., 2013, Język potoczny - dyskurs potoczny, w: E. Malinowska, J. Nocoń, U. Żydek-Bednarczuk (red.), Style wspótczesnej polszczyzny. Przewodnik po stylistyce polskiej, Kraków, s. 35-48.

Steil L., Miller W.D., 1982, Effective listening, Minnesota.

Słownik terminów literackich, 2008, (red.) M. Głowiński, Wrocław.

Stempek I., Stelmach A., Dawidek S., Szymkiewicz A., 2013, Polski, krok po kroku 1, Kraków.

Wojtak M., 2001, Styl urzędowy, w: J. Bartmiński (red.), Współczesny język polski, Lublin, s. $155-171$. 


\section{ANEKS}

\section{Ćw. 1, gra symulacyjna}

Student: Jesteś studentem na Wydziale Nauk Społecznych. Całe wakacje pracowałeś za granicą, by zapłacić za studia. Dziś masz ważny egzamin. Jeśli go zdasz, będziesz mógł jechać z dziewczyną i przyjaciółmi na wymarzone wakacje. Niestety autobus, którym jedziesz, psuje się i spóźniasz się na egzamin. Sekretarka nie chce cię dopuścić do profesora. Gdy wreszcie go widzisz, jest już za późno. Profesor chce już wyjść. Błagasz go, by pozwolił ci zdawać, ale on się nie zgadza. Jesteś zdesperowany.

Profesor: Jesteś profesorem na Wydziale Nauk Społecznych. Masz dziś wyjątkowo zły dzień. Boli cię głowa i chcesz jak najszybciej wrócić do domu. Egzaminujesz dziś studentów od godziny 11.00 do 12.00, ale masz nadzieję, że egzamin szybko się skończy. Sekretarka ciągle ci przeszkadza. O 11.50 nagle wchodzi student, który się spóźnił. Jesteś bardzo zdenerwowany. Mówisz mu, że dziś nie może już zdawać egzaminu, ale student nie chce wyjść.

Sekretarka: Pracujesz jako sekretarka na Wydziale Nauk Społecznych. Masz nadzieję, że profesor, z którym pracujesz pójdzie wreszcie do domu, ponieważ od rana ma bardzo zły humor. Jest niemiły i niesympatyczny. Proponujesz mu kawę lub herbatę. Gdy profesor już ma wyjść, wchodzi student i chce zdawać egzamin. Mówisz mu, że to niemożliwe i że musi przyjść w innym terminie. Student bardzo chce porozmawiać z profesorem. Ostatecznie pozwalasz mu na to.

\section{Ćw. 2, kończenie zdań po obejrzeniu informacji telewizyjnej i ćwicze- niach leksykalnych}

1. Ludzie zostali ewakuowani z Czarobyla, ponieważ...

2. Jeden z pracowników miał na piersiach ochraniacz, ale...

3. Radioaktywna chmura rozeszła się po całej Europie, bo...

4. Nie wiemy, ile osób zginęło dlatego, że...

5. Dziennikarz nakręcił materiał, ale...

6. Do katastrofy doszło 30 lat temu, ale .. 


\title{
Ćw. 3, czytanie, analiza tekstu uproszczonego
}

\section{Przyklad tekstu uproszczonego:}

\author{
Aldona Skudrzyk, Jacek Warchala: Język potoczny
}

Badania nad językiem potocznym, prowadzone w ostatnich latach XX wieku, dziś już nie są tak popularne. Jeśli porównamy pierwsze prace z dzisiejszymi (Adamiszyn 1995), zauważymy, że badacze koncentrowali się przede wszystkim na gramatyce tego języka. Badano język potoczny, porównywano go z innymi odmianami, przygotowywano typologie, opisywano język potoczny jako odmianę języka oficjalnego, która ma formę mówioną (Furdal, Gajda, Skubalanka, Wilkoń; zob. Wilkoń 2000); obserwowano też wzrost popularności języka potocznego.

\section{Literatura}

Adamiszyn Z., 1995, Styl potoczny, w: S. Gajda (red.), Przewodnik po stylistyce polskiej, Opole.

Wilkoń A., 2000, Typologia odmian współczesnej polszczyzny, Katowice.

Tekst opracowany na podstawie: Skudrzyk A., Warchala J., 2013, Język potoczny - dyskurs potoczny, w: Style wspótczesnej polszczyzny, (red.), E. Malinowska, J. Nocoń, U. Żydek-Bednarczuk, Kraków 2013, s. 35-48

\section{Tekst oryginalny}

Badania nad potocznością - odmianą lub stylem, lub językiem potocznym, bardzo dynamicznie rozwijane w trzech ostatnich dekadach poprzedniego wieku, dziś już nieco osłabły, a z całą pewnością zmieniły swój pierwotny charakter i początkową temperaturę. Jeśli przyjrzymy się pracom badawczym i pierwszym ich podsumowaniom (Adamiszyn 1995), zauważymy, że pierwotnie zainteresowanie badaczy skupiało się przede wszystkim na formalno-strukturalnej charakterystyce języka potocznego. Analizowano potoczność w jej odmianowej postaci, zestawiano i porównywano z innymi odmianami, konstruowano typologie języków/ odmian językowych, uwzględniające potoczność jako jedną z odmian języka narodowego w jego mówionej postaci (Furdal, Gajda, Skubalanka, Wilkoń; zob. Wilkoń 2000); obserwowano też zauważalny już wzrost znaczenia odmiany potocznej względem innych odmian językowych. 
Ćw. 4, pisanie sterowane listu motywacyjnego na podstawie weześniej dostarczonego wzorca i po przeprowadzonych ćwiczeniach leksykalnych

\section{„Wydawnictwo Śląsk" \\ Dzial Personalny}

Szanowni Państwo,

uprzejmie proszę o mojej kandydatury na stanowisko specjalisty ds. marketingu.

Posiadam kilkuletnie w pracy na podobnym stanowisku. Pracowałem w i

W wymienionych firmach kontaktowałem się z organizowałem przygotowywałem

Obecnie pracuję na stanowisku Jestem odpowiedzialny za W ramach moich obowiązków analizuję

i przygotowuję jestem Posiadam zdolności oraz umiem

Mam nadzieję, że zainteresuje Państwa moje podanie.

W razie jakichkolwiek pytań proszę o

Łączę

Maria Czempka-Wewióra

\section{SCIENTIFIC AND OFFICIAL STYLES IN PREPARATORY COURSES OF POLISH AS A FOREIGN LANGUAGE FOR PERSONS PLANNING TO STUDY IN THE POLISH LANGUAGE}

Keywords: glottodidactics of the Polish language, academic style, official style

Summary. Foreigners who decide to study in Poland often do not speak Polish at all or speak it very poorly. They need one year to learn the language enabling them to succeed in the following year in studies at their chosen university in Poland. During this preparatory course, it is not enough sufficient to only use one of popular textbooks for teaching the Polish language, since mastering the academic and official styles is a very important prerequisite. These styles are reflected in all language skills and should be practiced while teaching all of them. Students should master certain genres, language functions and selected structures both in speech and in writing. 